\title{
Facebook: Facilitating Social Access and Language Acquisition for International Students?
}

Kent Lee and Leila Ranta

Many international students come to Canada to improve their English language proficiency and develop friendships with Canadians and other international students. However, gaining access to host nationals (i.e., Canadians) is not an easy task for most English as a second language (ESL) learners. Factors such as language proficiency may hamper students' ability to build relationships with English speakers, which in turn contributes negatively to linguistic development and psychological well-being. One way we can help ESL students interact outside of class is to use a social networking site such as Facebook. The present study surveyed adult ESL students about their use of Facebook and whether that use was associated with social connections with host nationals. Results from the survey of 125 international students at a Canadian university show that the majority of students were using Facebook. Correlation analyses suggest weak associations between (a) Facebook use and social connections with the local community and (b) Facebook use and self-assessed language proficiency, with the strongest association being to oral proficiency. Simply possessing a Facebook account is unlikely to increase social connectedness with host nationals. Suggestions for language teachers on integrating Facebook into their classes are provided.

Plusieurs étudiants internationaux viennent au Canada pour améliorer leur compétence en anglais et développer des amitiés avec des Canadiens et avec d'autres étudiants internationaux. Il reste, toutefois, qu'il n'est pas facile pour la plupart des apprenants d'ALS de communiquer avec les Canadiens. Des facteurs comme la compétence langagière peuvent entraver la capacité des étudiants à établir des rapports avec des locuteurs d'anglais, ce qui peut nuire au développement linguistique et au bienêtre psychologique des apprenants. Parmi les façons d'appuyer l'interaction des étudiants d'ALS avec les Canadiens, notons l'emploi de sites de réseautage social comme Facebook. La présente étude porte sur un sondage auprès des étudiants d'ALS pour déterminer leur emploi de Facebook et dans quelle mesure il a contribué à l'établissement de liens sociaux avec les Canadiens. Les résultats du sondage effectué auprès de 125 étudiants internationaux à une université canadienne ont démontré que la majorité des étudiants employaient Facebook. Des analyses de corrélation révèlent des associations faibles entre (a) l'emploi de Facebook et les liens sociaux avec la communauté locale et (b) l'emploi de Facebook et les autoévaluations de compétence linguistique. L'association la plus forte était avec la compétence orale. Il est peu probable que le simple fait 
d'avoir un compte Facebook accroisse les liens sociaux avec les Canadiens du pays d'accueil. On offre aux enseignants de langue des suggestions pour intégrer Facebook dans leurs cours.

Teachers working in the field would likely agree that pressure is mounting to incorporate technology into their teaching practices. For example, the Government of Alberta recognizes that "e-learning is gaining momentum" and has funded initiatives to help professionals recognize the importance of technology in learning (Light, 2010, p. 2). The language classroom is not exempt from the shift toward including technology; the premise for utilizing computer-assisted language learning (CALL) with ESL learners has much support in the literature. For instance, Macaro, Handley, and Walter's (2012) systematic review of 47 research studies concerning CALL and ESL education in primary and secondary schools between 2000 and 2010 presented evidence of technology contributing to the development of language skills. Numerous different types of technology were used in those studies. Of concern to the L2 teacher is the question of what types of computer technology are likely to lead to significant improvement in their learners' L2 abilities.

A current trend in technology and teaching is online learning. Arguably, social networking constitutes the most novel and ubiquitous component of the online environment. With an ever-increasing number of people migrating toward the digital frontier, it would be appropriate to examine the feasibility of exploiting the readily accessible community of English language speakers on the Internet via social networking. For instance, the social networking site, Facebook, claims to have 1.28 billion monthly active users as of March 2014 (http://newsroom.fb.com/company-info/) and may be a potential avenue of interaction between ESL learners and native or proficient speakers of English. A dominant theory in second language acquisition (SLA) posits that engaging in interaction facilitates the acquisition process by providing opportunities for learners to receive input, produce output, and receive feedback where meaning is the focus (Gass \& Mackey, 2006; Long, 1996).

Unfortunately, many adult ESL students (especially international students) have limited contact with native speakers (NS) and interact more extensively with co-nationals who speak their L1 (e.g., Ranta \& Meckelborg, 2013). Not only does this mean that an opportunity to enhance speaking skills in English has been missed, but the lack of interaction outside of the classroom may also have negative psychological effects on students. Feelings of alienation and isolation from the target language culture have been observed, particularly among learners from non-European backgrounds (Schram \& Lauver, 1988; Sodowsky \& Plake, 1992; Takayama, 2000; Trice, 2004).

The goal of this study was to examine ESL learners' use of Facebook and its relationship with learners' proficiency and willingness to communicate, and to explore whether the use of Facebook led to opportunities for social 
contact with target language speakers who were host nationals (i.e., local students). Below, we review the linguistic and social/psychological benefits of interaction, current knowledge about technology-mediated interaction among L2 learners, and research involving social networking sites.

\section{Literature Review}

\section{Linguistic and Psychological Benefits of Interaction}

The cognitive interactionist paradigm is currently one of the most important theories of SLA. In their assessment of 174 studies on second-language interaction, Plonsky and Gass (2011) pointed out that the bulk of and most compelling evidence in interaction research comes from research in corrective feedback conducted in laboratory and classroom settings. A growing body of research, carried out primarily using referential communication tasks, provides evidence of the linguistic benefits of face-to-face interaction between native speakers and L2 learners and between learners and learners (e.g, Keck, Iberri-Shea, Tracy-Ventura, \& Wa-Mbaleka, 2006; Mackey \& Goo, 2007). Conclusions from meta-analyses provide strong empirical support; when compared with the results of learners who engage in little to no interaction, not only did interaction lead to significant and sizable effects on language learners' proficiency gains in lexis and grammar, but these positive effects for grammar actually increased up to a month later. ${ }^{1}$ McDonough (2007) found in a study with 106 EFL participants that conversational feedback, such as clarification requests, promoted the acquisition of the English simple past morphology with activity verbs. To further illustrate the importance of interaction, we can even find evidence of interaction helping students acquire English articles (Sheen, 2007), a grammatical structure that many teachers know to be difficult. In a study with 99 ESL students of varying L1s learning the English definite and indefinite articles, Sheen found that students in the treatment group who received metalinguistic corrections outperformed the control group who received no interactional feedback. Sheen concluded it is possible that other types of feedback through which learners are pushed to modify their output, as hypothesized by Swain (1995), would be even more effective.

\section{Psychological Benefits of Interaction}

Humans have a fundamental need to belong and a drive to form stable interpersonal relationships that are more satisfactory than transient ones (Baumeister \& Leary, 1995). Failure to meet fundamental needs can lead to enduring ill effects. Baumeister and Leary found that forming social bonds is associated with positive emotions; in fact, even potential or imagined increases in one's belongingness is linked to positive changes in affect; social exclusion, on the other hand, can lead to anxiety and depression. Heller and 
Rook (2001) argued that social relationships or interactions can strengthen one's identification with the social group, raise one's self-esteem, provide help in times of stress, provide practical help with achieving one's goals, and deter individuals from engaging in socially unacceptable risky behaviour. While it is certain that international students can and do receive these benefits from social interaction with compatriots or international students from other countries, their relationships with host nationals have the potential to create feelings of belonging to the larger community. This might explain the observed relationship between feelings of well-being and amount of contact with local students. Furthermore, Bessière, Kiesler, Kraut, and Boneva's (2008) longitudinal study with a national sample of US households revealed that those who "used the Internet for communicating with friends and family ... showed lower depression scores six months later" (p. 47).

\section{Problems Connecting with Native Speakers}

Despite the benefits associated with having ample L2 interaction, many nonnative English-speaking international students at North American universities are reported to have only limited opportunities to establish personal relationships with host nationals. For example, Ranta and Meckelborg (2013) used a computerized log to measure Chinese graduate students' exposure to English at a Canadian university. The detailed analysis of learners' interactional behaviour over a period of 6 months, while revealing considerable variation among learners, showed an overall low average of 10.9 minutes a day spent conversing one-on-one with an English speaker. Similar findings have been reported in the study-abroad literature (e.g., Kinginger, 2011), suggesting that there are strong barriers to making contact with members of the target language community. Many factors have been suggested. Of these, low target language proficiency is a major barrier. In their interviews with 49 international students at a Canadian university, Heikinheimo and Shute (1986) identified English proficiency as the main difficulty for international students wishing to access NSs in a foreign country. Low English proficiency has two effects: first, it leads to more time required for reading and preparing assignments and less time available for social interaction. Second, it increases the difficulty of sustaining interactions with competent target language users due to the energy required by both parties to keep the conversation flowing. Finding NSs who are willing to engage in the more demanding task of comprehending an L2 interlocutor poses a challenge.

Inadequate knowledge of the host culture and undeveloped intercultural communication skills may also be an issue. Trice (2004) surveyed 497 international graduate students at a U.S. university and found that students from western European countries generally interacted more with Americans than did East Asians. In an ethnographic study, Takayama (2000) looked at 20 male Japanese students and their study abroad experiences in Vancouver, 
Canada. Despite efforts made by the Japanese students to make connections with Canadians, the majority of them failed to make Canadian friends. We interpret friend as a person whom one knows and likes, and with whom one would voluntarily invest his or her leisure time. These studies, and many others, suggest that cultural differences make it difficult for international students to make friends, since establishing personal relationships involves unwritten rules of how one is supposed to behave; it comes as no surprise that newcomers are unable to play the game upon arrival in a new context (Yates, 2004).

While language proficiency may act as a barrier to international students' ability to access local communities, it is also true that whether or not to initiate and continue communication with others is an individual choice. There are students who have low levels of proficiency in their second language yet choose to engage in as much interaction as possible, while some high-proficiency-level students shy away from communication. The concept willingness to communicate (WTC) offers an explanation for this phenomenon. WTC is defined as the likelihood of engaging in communication when one has the option to do so (McCroskey \& Richmond, 1990). MacIntyre, Clément, Dörnyei, and Noels (1998) have conceptualized a theoretical model of WTC in the L2 in the form of a six-layered pyramid comprising six categories or variables. The layers from bottom to top are social and individual context, affective-cognitive context, motivational propensities, situated antecedents, behavioural intention, and communication behaviour; each lower level functions as a prerequisite for the one above. An explanation for why some ESL students jump at the opportunity to communicate while others hide can be derived from this model. According to the WTC model, before L2 use occurs, one must have the intention to engage in communication. The behavioural intention, in turn, is influenced by "state communicative self-confidence" and a desire to communicate with a specific person. State communicative self-confidence includes emotions such as anxiety and "the feeling that one has the capacity to communicate effectively at a particular moment" (MacIntyre et al., 1998, p. 549). An individual's L2 proficiency is part of the model, but sits in the fifth layer. Therefore, learners' self-confidence in their communicative abilities in a given situation has a more immediate effect on their WTC than their actual proficiency.

\section{Computer-mediated interaction: Evidence of the linguistic effects of online communication}

Broadly speaking, computer-mediated communication (CMC) encompasses a variety of tools ranging from asynchronous text-based methods (e.g., e-mail or online forums) to synchronous types that could include a combination of text, audio, and video (e.g., Skype). Given the importance of interaction in SLA, Smith (2004) argued that online interlocutors engaging in meaning 
negotiations via CMC receive the same scaffolding and benefits afforded to interlocutors in face-to-face interactions (e.g., Blake, 2000; Blake \& Zyzik, 2003; de la Fuente, 2003). In an exploratory study with college-level Spanish learners, Yanguas (2010) found that the interaction patterns using video $\mathrm{CMC}$ were very similar to face-to-face interactions and equally successful. Some may even argue that CMC offers potential benefits over face-to-face. For example, more inhibited and shy learners may find CMC to be less threatening, and thus they increase their participation (e.g., Warschauer, 1996). In a study with female Japanese university students, Freiermuth and Jarrell (2006) found that online communication enhanced the participants' willingness to communicate by offering a more comfortable environment than face-to-face settings.

Online communication can offer benefits for language learning. Smith's (2004) study with intermediate-level English learners, performing tasks via synchronous written $\mathrm{CMC}$, found that learners engaged in negotiated interaction during the task when they encountered unknown vocabulary words. Moreover, the results suggest that those negotiated lexical items were more likely to be retained. Sauro and Smith (2010) analyzed video-enhanced chat transcripts of 23 university-level learners engaged in synchronous written $\mathrm{CMC}$ for linguistic complexity, lexical diversity, use of grammatical gender, and evidence of planning. They found significantly higher levels of syntactic complexity, as measured by lexical diversity and c-units (communication units), in the chatscripts that displayed evidence of post-production monitoring. C-units are defined as independent clauses plus modifiers, and include "isolated phrases not accompanied by a verb, but which have a communicative value" (Crookes, 1990, p. 184). For example, in the dialogue Where's my wallet? answered by Under the chair, the question and response are each a c-unit. The authors concluded that L2 learners carefully plan and monitor their production by capitalizing on the increased amount of planning time provided by chat. In a study with 58 university-level L2 students engaging in a jigsaw task, Yanguas (2012) found that synchronous oral CMC promotes vocabulary acquisition and retention.

\section{Social Networking Sites in Language Learning}

Social networking sites (SNS) are a form of CMC that uses the Internet. In recent years, SNS such as Facebook and Twitter have proliferated in people's everyday lives across the globe. Facebook offers both synchronous and asynchronous options for online communication, with the main mode being writing. While relatively few in number, studies about using SNS in the language classroom have shown some positive effects on learning. Blattner, Fiori, and Roulon (2009) explored the possibility of integrating Facebook into the foreign language classroom. Students in five Spanish and French as a foreign language classes were asked to join Facebook, and a specific class group was 
created by the instructor. One class also engaged in a language awarenessraising task: they had to find Facebook groups composed of members of the target language community and then analyze the language used by those groups. This task exposed students to pragmatic norms and authentic language that was used in context. Blattner et al. found a positive effect on relationships among the students themselves and between the students and their teacher as measured by an attitudinal questionnaire. In general, the students enjoyed connecting with one another on Facebook, and they had no objections to online self-disclosure, which, in turn, encouraged interaction in and out of class.

Similar positive reactions to the use of Facebook were found by Kabilan, Ahmad, and Abidin (2010) in their study at a Malaysian university. They surveyed students about their general Facebook usage practices and their perceptions of its role as an avenue to improving their English. The researchers found that the majority of students believed Facebook functions as a useful online environment to learn English as it allows them to practice using English, boosts their confidence in their English communication skills, increases their motivation to communicate in English, and brings about a more positive attitude toward learning English as an L2. The researchers concluded that Facebook offers students opportunities to engage in meaningful language use with their peers.

Hung and Yuen (2010) looked at the impact of supplementing face-to face courses with SNS in university courses in Taiwan. As well as being asked to engage in online discussions, participants were encouraged to create online profiles and share their interests and photos on a networking site accessible only by class members. The majority of the students indicated that the use of SNS promoted feelings of social connectedness and led to a positive attitude toward their learning experience. It should be noted that all of the participants already use computers in learning and everyday life, and $76 \%$ were members of one or more social networking sites in addition to the one in this study. It may be possible to leverage our learners' enthusiasm for social networking as a means to connect them with target culture members in the digital environment (Blake, 2011).

Ellison, Steinfield, and Lampe (2007) collected data through a survey of 286 undergraduate students in a U.S. college; not only did they find associations between Facebook use and social ties, but their data also suggested that Facebook use can help with life satisfaction. Regression analyses revealed Facebook use to be a significant predictor of individuals' social capital, which refers to the number of resources individuals have through their relationship with others (Coleman, 1988). Ellison et al. (2007) suggested that Facebook may lower barriers to communication, as it offers different ways for users to connect. It is also relatively easy for users to keep in touch with friends near and far. They also found an interaction between bridging and bonding social capital (the former refers to relationships that lack emotional 
support and the latter to emotionally close relationships) and subjective well-being measures. Facebook use indeed varied, depending on a student's psychological well-being. "Facebook use may be helping to overcome barriers faced by students who have low satisfaction and low self-esteem" (Ellison at al., 2007, p. 1163). However, because the sample population was undergraduate students in the U.S. from a single institution, the findings may not be generalizable to other populations. The authors also explicitly stated "the extremely low incidence of ... international students in our sample hampered our ability to assess the effects of Facebook membership on these groups" (p. 1164).

Despite the fact that ESL learners receive instruction and practice situations in the language classroom, classroom and real-world interactions differ in that students transform from being a language learner in the classroom to a language user in the real-world (Springer \& Collins, 2008). Although studies mentioned earlier in the literature review show SNS to be promising in terms of contributing to language learning success, we have found only one study specifically exploring the use of Facebook by students in an ESL context for the purpose of meeting host nationals. Mitchell (2012) conducted a small-scale qualitative study with seven international students living in the United States, examining their reasons for joining Facebook, their abilities in meeting those reasons, and factors that encouraged or hindered Facebook use. Participants identified making and maintaining existing friends, learning about American culture, and Facebook's novelty as reasons for joining. Two of the seven reported "making new friends through Facebook groups, but these friendships did not develop into face-to-face friendships" (p. 484). The author conceded that in no way can the finding be generalized due to the small sample size.

Through a survey of 213 students, Madge, Meek, Wellens, and Hooley (2009) observed that new undergraduate students used Facebook to make new friends (face-to-face and virtual), and Facebook acted as a "social glue" that helped them settle into university life. As noted, international ESL students often have trouble meeting NSs; thus, we approached the problem with a naïve view that Facebook might be a gateway to accessing NSs. Therefore, the goal of this exploratory study was to investigate the relationship between ESL learners' use of Facebook and their contact with host nationals (i.e., Canadians). The research questions of this study were as follows:

1. Do participants in this study use Facebook and, if so, in what language?

2. Is there a significant positive linear relationship between the use of Facebook and social interactions with host nationals?

3. Is there a significant positive linear relationship between an individual's willingness to communicate and their use of Facebook?

4. Is there a significant positive linear relationship between a learner's proficiency level in English and their use of Facebook? 


\section{Method}

The design of the present study partially replicates Ellison et al.'s (2007) study. Data were collected by means of a questionnaire, which solicited information about participant demographics, measures of Facebook usage and social connections, a measure of willingness to communicate, and language ability self-assessment. Each part of the questionnaire is described below.

\section{Instruments}

We used a four-part questionnaire (see Appendix) to collect data for the present study. The questionnaire was presented in English, was hosted on the online survey website Survey Monkey (www.surveymonkey.com), and contained the following subsections:

Demographics. Eight items in the demographics sections elicited information about the participants' background, living arrangements, current ESL education, and their possession of a Facebook account. The items were questions with yes/no or one-word answers.

Facebook usage. We adapted the questionnaire created by Ellison et al. (2007) for measuring Facebook usage. The questions were slightly modified to reflect the context of the current study (e.g., city name). We also introduced new questions pertinent to the sample population (e.g., "Using Facebook has helped me to become better friends with Canadians"). This section asked participants to report the number of Facebook friends they had, the amount of time they spent on Facebook, the language in which they used Facebook, and the amount of personal information they shared in their profiles. A series of Likert-scale attitudinal questions measured the degree to which participants were connected to Facebook and the extent to which Facebook usage was integrated into their daily routines. Some items also examined whether participants used Facebook to maintain existing social connections or to meet new people, and whether Facebook had helped them strengthen their relationships with host nationals.

Social connections. The social connections section was adapted from the Bridging Social Capital Scale and Bonding Social Capital Scale from Ellison et al.'s (2007) questionnaire, which was adapted from Williams' (2006) Internet social capital scales. Again, we changed the wording to better suit the participants and to fit the context of the present study. As we were not interested in the difference between bridging and bonding social capital, we grouped the two separate measures under one category: social connections. A series of Likert-scale items examined the participants' degree of sense of belonging to their local community, and the number and quality of their social relationships with others. We collapsed the 13 questions into one variable.

Willingness to communicate. The Willingness to Communicate scale was adapted from McCroskey's (1992) WTC scale. It includes 20 items (12 are used to score and 8 are fillers) that are designed to measure the participants' 
"predisposition toward approaching or avoiding the initiation of communication" (p. 17).

Language ability self-assessment. The Council of Europe's Self-Assessment Grid for Language Learning (http://www.coe.int/t/dg4/education/elp/elpreg/Source/assessement_grid/assessment_grid_english.pdf) served as this final measure. Commonly used in Europe (e.g., North, 2007), it has a series of performance-based statements in the areas of reading, listening, spoken interaction, spoken production, and writing. The grid contains six levels of proficiency (A1 to $\mathrm{C} 2$ ) for each area. Levels $\mathrm{A} 1$ and $\mathrm{A} 2$ categorize a basic user who can generally function in the L2 for immediate needs. Levels B1 and B2 refer to intermediate users who interact with NSs when dealing with familiar topics. Levels $\mathrm{C} 1$ and $\mathrm{C} 2$ describe proficient users who are native- or nearnative-like in their L2 abilities. Participants were asked to choose what they considered the best descriptor of their abilities in each of the language skill categories.

\section{Participants}

The English Language Program at a local university served as the data collection site. Nine classes of adult ESL learners enrolled in an intensive day program (IDP) took part in the study. According to the university's website, the goal of the IDP was to help students develop in the four skills of listening, speaking, reading, and writing in order to prepare them for academic, professional, and social settings. Students in the IDP attended a 4-hour class five times a week. They were also eligible to apply for employment opportunities on the university's campus.

A total of 131 students agreed to take part in the study. Of the 131 participants who began the survey, 125 (95.4\%) completed it. The sample group consisted of $70(56.0 \%)$ males and $55(44.0 \%)$ females who ranged in age from 17 to $38(M=23.1, M d n=22)$. The participants represented 20 different countries with 11 different first language groups, and their length of residence in Canada ranged from less than one month to three years $(M=$ 7.19 months). Of the eight levels of ESL classes offered in the IDP, five levels were represented (ESL 115, 120, 125, 130, 135), all of which were at an intermediate level or above (categorization based on in-house assessments). The mode in terms of the respondents' class enrollment was the advanced ESL 135 class $(36.8 \%)$. The second largest group was the high intermediate ESL 125 class $(26.4 \%)$.

\section{Procedure}

The teachers in the program granted us access to their classes and provided us with 30 minutes of their computer lab time for the students to complete the online questionnaire. We group-administered the questionnaire to students who voluntarily participated one class at a time in January 2009. The website 
allowed for encrypted data transmission for security purposes during collection and data download.

\section{Results}

\section{Demographics}

In terms of living arrangements, $7.9 \%$ of the respondents reported living alone, 50\% lived with someone who spoke their L1, and $42.1 \%$ lived with someone who spoke a language other than their L1. With regard to our first research question, $60 \%(n=75)$ reported yes to possessing a Facebook account and $40 \%$ no.

\section{Facebook Usage}

Of the 125 participants, 75 possessed a Facebook account, and the results in the following sections are based on these 75 Facebook members. We found that $70 \%$ of the respondents had set their Facebook account in English while the other 30\% used their first language. We found that $69 \%$ used mainly English to communicate, $20 \%$ used their first language, and the remaining $11 \%$ claimed to use a mixture of English and the first language. In addition, we measured intensity of Facebook use and attitudes toward Facebook. The wording for each item in this measure and the summary statistics are presented in Table 1.

\section{Table 1}

\section{Summary Statistics for Facebook Intensity $(n=75)$}

\begin{tabular}{lrr}
\hline $\begin{array}{l}\text { Individual items and scale for Facebook intensity (Cronbach's } \\
\text { alpha }=0.86 \text { ) }\end{array}$ & SD \\
\hline $\begin{array}{l}\text { About how many total Facebook friends do you have? } 1=10 \\
\text { or less, } 2=11-50,3=51-100,4=101-150,5=151-200,6=\end{array}$ & \\
201-250, $7=251-300,8=301-400,9=$ more than 400 & 2.65 & \\
In the past week, about how much time did you spend on Face- & & \\
book? $1=0-30$ minutes, $2=0.5-1$ hour, $3=1.5-2$ hours, $4=$ \\
2-2.5 hours, $5=2.5-3$ hours, $6=3-3.5$ hours, $7=3.5-4$ hours, & 3.06 & 3.19 \\
$8=4-4.5$ hours, $9=$ over 5 hours & 2.75 & 1.265 \\
Facebook is part of my everyday activity & 2.87 & 0.984 \\
I am proud to tell people that I'm on Facebook & 2.57 & 1.254 \\
Facebook has become part of my daily routine & & \\
I feel out of touch with people if I don't use Facebook for a few & 2.26 & 1.146 \\
days & 2.67 & 1.184 \\
I feel I am part of the Facebook community & 2.75 & 1.253 \\
\hline I would be disappointed if Facebook shut down
\end{tabular}

Note. Unless provided, response categories ranged from 1 (strongly disagree) to 5 (strongly agree). Adapted from Ellison et al. (2007). 
Other questions provided further insight into the participants' ratings of the potential benefits of Facebook (Table 2). We asked three questions to determine the participants' perceptions of whether Facebook helped them to make or become better friends with others. The results showed that students felt using Facebook did not help them to meet new host nationals nor strengthen existing relationships with them. As for relationships with people from other countries, students appeared to be neutral in their attitudes toward Facebook's role in helping them strengthen friendships. We also asked if participants were using Facebook's synchronous chat function and online invitations, and the results showed that students' attitudes were neutral ( $M$ $=3.19$ and 2.70 , respectively). Further investigation revealed that $54 \%$ of the students' total Facebook friends were from their home countries, while only $6 \%$ were local Canadians.

Table 2

Summary Statistics for Student Attitudes of Facebook Benefits $(n=75)$

\begin{tabular}{lcr}
\hline Items (Cronbach's alpha =0.83) & $M$ & $S D$ \\
\hline Using Facebook has helped me to meet new Canadians & 2.43 & 1.068 \\
Using Facebook has helped me to become better friends with & & \\
Canadians & 2.68 & 1.002 \\
Using Facebook has helped me to become better friends with & 3.12 & 1.065 \\
people from other countries & & \\
I use Facebook's chat function to talk with friends in English & 3.19 & 1.372 \\
I use Facebook to invite friends to events in [city] & 2.70 & 1.119 \\
\hline
\end{tabular}

Note. Individual items ranged from 1 (strongly disagree) to 5 (strongly agree).

We followed Ellison et al.'s (2007) method of determining whether students were using Facebook to meet new people or connect with people they already knew offline (see Table 3). A $t$-test was used to compare the mean scores for the off to online scale with the on to offline single item. The data in Table 3 show that students used Facebook with people they knew in real life $(M=3.002)$ significantly more than they did to meet new people $(M=2.69)(t$ $=2.967, p<0.005$ ).

Results from the social connections section of the survey revealed that, on average, the participants rated all the items above neutral (i.e., they tended to agree), with the exception of the item "I meet new English-speaking Canadians in [city] all the time" (see Table 4), suggesting that students did, in fact, meet Canadians whom they did not already know. To further explore the possibility of Facebook's association with meeting host nationals, we decided to correlate that single item with Facebook intensity and found a very weak association that was not significant $(r=0.18)$. 
Table 3

Summary Statistics for Facebook use for prior contacts and meeting new people $(n=75)$

\begin{tabular}{lcr}
\hline Individual items and scale & $M$ & $S D$ \\
\hline $\begin{array}{l}\text { Off to online: Use Facebook to connect with offline contacts } \\
\text { (Cronbach's alpha = 0.87) }\end{array}$ & 3.002 & 0.238 \\
I have used Facebook to learn more about someone I met so- \\
cially in person \\
I use Facebook to learn more about other people in my classes \\
$\begin{array}{l}\text { I use Facebook to learn more about my classmates from other } \\
\text { cultures }\end{array}$ & 2.94 & 1.11 \\
$\begin{array}{l}\text { I use Facebook to learn more about other people living near me } \\
\text { in [city] }\end{array}$ & 2.07 & 1.083 \\
$\begin{array}{l}\text { I use Facebook to learn more about Canadians living near me } \\
\text { I use Facebook to keep in touch with my friends from my home } \\
\text { country who live in [city] }\end{array}$ & 2.78 & 1.066 \\
$\begin{array}{l}\text { I use Facebook to keep in touch with my friends from other } \\
\text { countries in [city] }\end{array}$ & 2.87 & 1.259 \\
I use Facebook to keep in touch with my Canadian friends in \\
[city] \\
$\begin{array}{l}\text { I use Facebook to keep in touch with my friends who are living } \\
\text { back home } \\
\text { On to offline: I use Facebook to meet new people (single item } \\
\text { measure) }\end{array}$ & 3.38 & 1.059 \\
\hline
\end{tabular}

Note. Individual items ranged from 1 (strongly disagree) to 5 (strongly agree). Adapted from Ellison et al. (2007).

Table 4

Summary Statistics for Social Connection Items $(n=75)$

\begin{tabular}{lrr}
\hline Individual items and scale & $M$ & $S D$ \\
\hline Social connections (Cronbach's alpha = 0.82) & 3.33 & 0.315 \\
I feel I am part of the [city] community & 3.00 & 0.952 \\
I am interested in what goes on in [city] & 3.48 & 0.958 \\
[city] is a good place to live & 3.29 & 1.055 \\
Interacting with people in [city] makes me feel like a part of Ca- & 3.37 & 0.875 \\
nadian society & & \\
I am willing to spend time to support or participate in events in & 3.5 & 0.994 \\
[city] & & \\
I meet new people in [city] all the time & 3.19 & 0.880 \\
I meet new English-speaking Canadians in [city] all the time & 2.93 & 0.985 \\
There are several people in [city] who I trust to help me solve & 3.63 & 0.894
\end{tabular}


There are several English-speaking people in [city] who I trust to

help me solve my problems

If I have an emergency and need to borrow $\$ 100$, I know some-

one in [city] who can help me

There is someone in [city] I can ask for advice about important

decisions

There is a Canadian in [city] I can ask for advice about important decisions

I do not know people in [city] well enough to ask anyone to do important things for me

Note. Individual items ranged from 1 (strongly disagree) to 5 (strongly agree). Adapted from Ellison et al. (2007).

\section{Willingness to Communicate}

Willingness to communicate was calculated using the WTC scale (McCroskey, 1992). The scale allows for measurement of WTC as seven subscores, each with a maximum score of 100, and a total score of 700 . We used the total score and subscores for WTC with a stranger, with an acquaintance, and with a friend for our analysis (see Table 5). A score of 0 meant that the respondent always avoided initiating communication, and 100 refers to a tendency to always approach and initiate communication. As expected, the mean scores for the group were highest for WTC with a friend $(M=75.6)$ and lowest for WTC with a stranger $(M=34.6)$.

Table 5

Summary Statistics for Willingness to Communicate $(n=75)$

\begin{tabular}{lrrr}
\hline Subscale & $M$ & $S D$ & $\alpha$ \\
\hline WTC global & 52.7 & 17.7 & 0.91 \\
WTC with a stranger & 34.6 & 21.1 & 0.74 \\
WTC with an acquaintance & 48.0 & 23.3 & 0.82 \\
WTC with a friend & 75.6 & 17.4 & 0.65 \\
\hline
\end{tabular}

Note. WTC ranged from 0 (never) to 100 (always).

\section{Proficiency in English}

Descriptive statistics on the participants' self-reported proficiency can be found in Table 6. The results showed that, as a group, the students rated themselves as intermediate users (global $M=3.19$ on the questionnaire translates to level B1 of the self-assessment grid). The highest scores on individual skills were found in reading and writing $(M=3.36$ and 3.23 , respectively). 
Table 6

Summary Statistics for Self-reported English Proficiency $(n=75)$

\begin{tabular}{lrr}
\hline Subscale & $M$ & $S D$ \\
\hline Global & 3.19 & 0.995 \\
Listening & 3.11 & 1.416 \\
Reading & 3.36 & 1.223 \\
Spoken interaction & 3.15 & 1.35 \\
Spoken production & 3.09 & 1.212 \\
Writing & 3.23 & 1.12 \\
\hline
\end{tabular}

Note. $1=\mathrm{A} 1,2=\mathrm{A} 2,3=\mathrm{B} 1,4=\mathrm{B} 2,5=\mathrm{C} 1$, and $6=\mathrm{C} 6$ on the Council of Europe's Self-

Assessment Grid for Language Learning.

\section{Relationship Between Facebook Use and Social Connections, WTC, and Proficiency}

For research questions 2, 3, and 4, we performed correlation analyses to determine if any significant linear relationships existed between Facebook use by ESL students and their connections to host nationals, their willingness to communicate, and their self-reported English proficiency levels (Table 7). We found only a weak association between the participants' Facebook use and their social connection with host nationals $(r=0.22, p<0.05)$, as well as with their global self-reported language proficiency $(r=0.21, p<0.05)$. There did not appear to be any association between Facebook use and willingness to communicate $(r=0.04)$. Further investigation into each subscale on the WTC revealed similar results (Table 8 ). We also examined correlations between Facebook use and each of the following language skills: writing, spoken production, spoken interaction, reading, and listening (Table 9). The results showed significant but low correlations between Facebook use and spoken production $(r=0.32, p<0.05)$, writing $(r=0.25, p<0.05)$, and spoken interaction $(r=0.25, p<0.05)$.

Table 7

Correlations Between ESL Students' Facebook Use, Social Connections, WTC, and Global Proficiency

\begin{tabular}{lrrr}
\hline Measure & Social Connection & WTC & Global Proficiency \\
\hline Facebook intensity & $0.22^{*}$ & 0.04 & $0.21^{*}$ \\
\hline
\end{tabular}

${ }^{*} p<0.05$

Table 8

Correlations between ESL Students' Facebook Use and WTC Subscales

\begin{tabular}{lrrr}
\hline Measure & Stranger & Acquaintance & Friend \\
\hline Facebook intensity & -0.05 & 0.06 & 0.09 \\
\hline
\end{tabular}


Table 9

Correlations between ESL Students' Facebook Use

and Proficiency in Different Skills

\begin{tabular}{lccccc}
\hline & & \multicolumn{2}{c}{ Spoken } & & \\
\cline { 3 - 4 } Measure & Writing & Production & Interaction & Reading & Listening \\
\hline Facebook intensity & $0.25^{*}$ & $0.32^{*}$ & $0.25^{*}$ & 0.02 & 0.00 \\
\hline
\end{tabular}

${ }^{*} p<0.05$

\section{Discussion}

Our first research question asked, "Are ESL students using Facebook?" The results showed that over half of the ESL students surveyed were using Facebook. Data about attitudes toward Facebook were not gathered for nonusers and therefore we cannot determine the reasons for their nonuse of Facebook. ${ }^{2}$ A high percentage of Facebook members reported having their accounts set in English, even though Facebook was available in their first language. It is possible that they were doing so in an attempt to gain more exposure to and practice in English. The results also showed that a high percentage of users conducted the majority of their communications on Facebook in English. Although the bulk of their Facebook friends were from their home countries, the fact that most of their communication was in English suggests that Facebook (and English) was used as a way to keep in touch with people who did not speak the same first language. Further evidence includes the finding that, on average, the participants tended to agree with the statement "I use Facebook's chat function to talk with friends in English." These other English users were likely to be ESL classmates or a small number of NSs, considering that a relatively large proportion of their day was spent in class. Given their low percentage of Canadian Facebook friends, it is not surprising to see that students did not feel that Facebook contributes to helping them meet new English speakers.

The significant difference found between using Facebook with real-life acquaintances versus meeting new people online was also unsurprising. This finding reflects results from Ellison et al.'s (2007) study with college students in the United States. In order to become friends with someone on Facebook, one has to initiate a request to become friends and the other has to accept. Although some people may randomly add unknown persons as friends, users are unlikely to add strangers haphazardly to their friends list because of the vast amount of personal information that is available to one's Facebook friends.

With regard to our second research question ("Is there a relationship between Facebook use and social ties with host nationals?"), it appears that our sample population faced the same difficulty in meeting host nationals as the ESL students mentioned in the literature review section. In the social 
connections section of our survey, the only item with which the participants tended to disagree was "I meet new English-speaking Canadians in [city] all the time." A number of factors offer a possible explanation for this observation. First, the participants spent four hours of their day in class with other ESL students. Some students worked in jobs outside of class, but their visa status meant that employment was confined to jobs on campus that were often filled by other international ESL students. School and work are usually good opportunities to meet new people, but if their primary interactions in these situations are with other ESL students, the likelihood of meeting and befriending NSs decreases. We did not collect data on students' activities outside of class time, but it is likely that they had little interaction with NSs, similar to findings in other studies (e.g., Kodama, 2007; Ranta \& Meckelborg, 2013).

The analysis showed no significant correlation between Facebook use and meeting new host nationals. As mentioned, students reported using Facebook with people they already knew, and therefore it is logical to conclude that Facebook was not associated with the creation of new friendships. Following Ellison et al.'s (2007) example, the social connections section of our survey measured the degree to which participants were integrated into the [city] community, their willingness to support the community, and their social ties. Similar to Ellison et al., we found a statistically significant, albeit weak, correlation between Facebook use and social connections. The results from the present study seem to support Valkenburg and Peter's (2009) hypothesis, based on findings from a decade of research in online communication, that online communication such as Facebook promotes social connectedness among participants. Again, students seemed to be bringing their offline world, which we speculate had few host nationals, to the online environment, but this would need to be corroborated by further research. Given that perception, one would not expect to see Facebook use associated with social connections to the students' host community unless they already had connections in the community offline. Nevertheless, we did find an association, suggesting that a sense of connection to the local community does not necessarily have to include host nationals but can develop through friendships with others, such as peers who are ESL learners; Facebook allows for the maintenance of these connections "cheaply and easily" (Ellison et al., 2007, p. 1162).

Although the present study did not look at psychological effects, students' use of Facebook to communicate with friends, even if those friends were not NSs, may have other benefits, such as reduced depression (Bessière et al., 2008). As well, interaction with the local ESL community may help students gain a feeling of belongingness and social inclusion, despite the lack of host nationals. Being able to meet the fundamental human need to belong through interaction with others in the local community, regardless of nationality, may contribute to positive changes in affect and reduce 
the possibility of experiencing depression that social exclusion could bring, as suggested by Baumeister and Leary (1995). The participants' social networks also appeared to provide some of the theoretical functions of social relationships listed by Heller and Rook (2001), for example, providing practical help. From the social connections section of the questionnaire, participants tended to agree with statements such as "There are people in [city] who I trust to solve my problems" and "If I have an emergency ... I know someone in [city] who can help me."

As one would expect, participants showed the highest scores for willingness to communicate on the friend subscale, followed by acquaintance and then stranger subscales. We expected that students with higher WTC scores to be using Facebook more, but that does not seem to be the case. In answer to research question 3, global WTC did not show statistically significant correlations with Facebook use. As Valkenburg and Peter (2009) stated, online communication enhances self-disclosure because it lowers inhibitions in disclosing personal information, which can be liberating for people who are shy and self-conscious. Perhaps communication through Facebook raises WTC (Freiermuth \& Jarrell, 2006) or lowers communication barriers to such a degree that WTC becomes a nonfactor.

With respect to research question 4, a significant but weak correlation was found between students' self-reported English language proficiency and Facebook use. Further examination revealed other statistically significant correlations with self-assessments of writing, spoken production, and spoken interaction abilities. One might expect the association between writing and Facebook use, as communication on Facebook is mainly text-based (one can post pictures, videos, or sound, but but these are less common methods than text by which to deliver a message to other people). For that reason, the absence of correlation between Facebook use and listening proficiency is unsurprising. What is surprising is the higher correlation found with spoken production. Because of Facebook's informal nature, the register used for communication on Facebook may resemble that of spoken speech. Therefore, students with higher spoken production abilities may do well in Facebook communication. Another explanation could be that interaction has the possibility of contributing to fluency development (e.g., Schmidt, 1992; Swain, 1993). Inherent in the self-assessment questionnaire choices for spoken production is a measure of fluency. Participants who have a higher Facebook intensity score were likely to have engaged in more interaction and therefore more practice, which could explain the observed positive correlation.

A number of limitations exist in the present study. First, the sample size of those who used Facebook was relatively small. A larger sample would allow for more sophisticated analyses. Second, continuous data were converted to categorical data following the practice of the original study on which this one was based. Third, we examined only one population of ESL students, mostly 
at the intermediate level, who were all in an intensive day program with other ESL students. This might have led to restriction in the range of scores, leading to lower correlations. It is possible that, were the study to be repeated with, for example, international ESL students who take academic classes with NSs, different patterns would emerge. Fourth, the present study was exploratory in nature and does not delve deeply into how ESL students are using Facebook or into other factors that aid or prevent them from meeting host nationals. Finally, as with any self-reported surveys, there are chances of misreported information that decrease reliability and could have contributed to the low correlations observed. In retrospect, data on usage might have been better gathered using a different instrument than a 5-point attitudinal scale. There is also the possibility that the scales for measuring proficiency and WTC may not have been sensitive enough to detect relationships. The quantitative results presented here provide a broader picture, but approaching the topic via qualitative research (e.g., Mitchell, 2012) might yield more in-depth information.

\section{Pedagogical Implications}

Over half of the students surveyed were using Facebook, with the majority of them using it in English to communicate. This may provide another opportunity for English use practice, and teachers should encourage their students to continue to use it. Unlike classroom interactions, communicating with friends on Facebook could be perceived as more authentic. The participants in this study do not appear to have many Canadian native speaker Facebook friends, which may be a reflection of their real-world situation. The results of this study showed that merely possessing a Facebook account and using it in English while living in the target language community was not associated with social connections - face-to-face or virtual - with host nationals (even if those people were one click away in the cyber world). The question is how teachers can tap into this vast resource of NSs and authentic language. One possibility is to follow Blattner et al.'s (2009) example of easing students into using Facebook. Teachers and students could use it as a source of authentic language for analysis. For example, as Blattner et al. suggests, sociopragmatic awareness can be developed through the observation of greetings, requests, apologies, refusals, and complaints made by NSs in other Facebook groups. Blattner et al. further suggested that once students are familiar and competent with Facebook interaction, the next step is to actively engage in communication and make meaningful connections with NSs by discussing topics of interest.

Teachers should not simply tell their students to sign up for a Facebook account and then randomly add friends. Instead, Facebook could be used to connect with people who students have met offline. For example, teachers can teach students that it may be appropriate to ask someone with whom they 
share a weak connection (e.g., someone whom they have just met) whether he or she has a Facebook account and if it would be okay to add them as a friend. In this example, a NS may be more inclined to add the ESL student as a friend on Facebook, as opposed to exchanging phone numbers; "friending" on Facebook may open up new avenues of interaction in the future. Once students and host nationals are friends on Facebook, they can communicate in a number of ways, including synchronous chat, private mail, public discussion threads, and the creation of invitations to events. ESL teachers can then teach proper communication etiquette in those areas. However, the problem of limited contact with NSs remain; perhaps by joining active online communities through, for example, Facebook's group pages or other SNS tools such as Twitter or Tumblr, international students may have more success in meeting host nationals. ${ }^{3}$

As an aside, we want to note that the purpose of this study was not to address privacy issues associated with Facebook. Some teachers (and students) may shy away from using Facebook due to privacy concerns. We believe that it would be worthwhile for those educators to familiarize themselves with the privacy controls and benefits that Facebook offers and then pass that knowledge onto their students.

\section{Conclusion}

The present study shows that, yes, some ESL students were using Facebook to connect with English-speaking friends; however, the data indicate that much of the interaction on Facebook was not with NSs. The lack of English NS Facebook friends could have been due to the lack of friends who were host nationals in the ESL students' lives. The results show that many of their interactions on Facebook were with people who shared an offline connection. If that is the case, then simply possessing a Facebook account will unlikely lead to an increase in social connections and interactions with host nationals. One cannot deny the popularity of Facebook with NSs in our society, and this study shows that a sizable proportion of ESL students are already on Facebook. Future research could look at how to exploit Facebook as a tool in connecting NSs with ESL learners. Research with other ESL populations would be worthwhile. In addition, there is room to explore how to implement Facebook as a language learning tool in the classroom and to study the language development benefits from doing so. The central issue at hand is finding ways to increase ESL students' interactions with NSs outside of the language classroom. Being able to access the target language community has both linguistic and psychological benefits, and we believe that, in addition to pursuing traditional avenues of access (e.g., volunteering), it would be worthwhile pursuing alternative avenues of access by means of technological tools. 


\section{Notes}

1 Of the 28 interaction studies meta-analyzed by Mackey and Goo (2007), eight studies employed longer-term delayed posttests.

2 This was not one of our research questions.

3 Thank you to the anonymous reviewer who provided this suggestion.

\section{Acknowledgement}

This study was conducted during the first author's work toward a MEd; I am grateful to the students and their teachers for their participation. We would both like to express our gratitude to audience members from our various conference presentations for their encouragement. Finally, thank you to TESL Canada Journal's editor and anonymous reviewers for their helpful comments.

\section{The Authors}

Kent Lee is a doctoral student in the TESL program at the University of Alberta. He also teaches immigrant students in literacy and academic upgrading programs at NorQuest College.

Dr. Leila Ranta is an associate professor in the TESL program in the Department of Educational Psychology at the University of Alberta.

\section{References}

Baumeister, R. F., \& Leary, M. R. (1995). The need to belong: Desire for interpersonal attachments as a fundamental human motivation. Psychological Bulletin, 117(3), 497-529.

Bessière, K., Kiesler, S., Kraut, R., \& Boneva, B. S. (2008). Effects of internet use and social resources on changes in depression. Information, Communication $\mathcal{E}$ Society, 11(1), 47-70.

Blake, R. (2000). Computer-mediated communication: A window on L2 Spanish interlanguage. Language Learning \& Technology, 4(1), 120-136.

Blake, R. J. (2011). Current trends in online language learning. Annual Review of Applied Linguistics, 31, 19-35. doi:10.1017/S026719051100002X

Blake, R. J., \& Zyzik, E. C. (2003). Who's helping whom?: Learner/heritage-speakers' networked discussions in Spanish. Applied Linguistics, 24(4), 519-544.

Blattner, G., Fiori, M., \& Roulon, S. (2009, March). Integrating Facebook in the language classroom: Possibilities and linguistic benefits. Paper presented at the annual conference of the American Association for Applied Linguistics (AAAL), Denver, CO.

Coleman, J. S. (1988). Social capital in the creation of human capital. American Journal of Sociology, 94, S95-S120.

Crookes, G. (1990). The utterance, and other basic units for second language discourse analysis. Applied Linguistics, 11(2), 183-199. doi:10.1093/applin/11.2.183

de la Fuente, M. J. (2003). Is SLA interactionist theory relevant to CALL? A study on the effects of computer-mediated interaction in L2 vocabulary acquisition. Computer Assisted Language Learning, 16(1), 47-81.

Ellison, N. B., Steinfield, C., \& Lampe, C. (2007). The benefits of Facebook "friends": Social capital and college students' use of online social network sites. Journal of Computer-Mediated Communication, 12(4), 1143-1168.

Freiermuth, M., \& Jarrell, D. (2006). Willingness to communicate: Can online chat help? International Journal of Applied Linguistics, 16(2), 189-212.

Gass, S. M., \& Mackey, A. (2006). Input, interaction and output: An overview. AILA Review, 19, 3-17.

Heikinheimo, P. S., \& Shute, J. C. M. (1986). The adaptation of foreign students: Student views and institutional implications. Journal of College Student Personnel, 27(5), 399-406.

Heller, K., \& Rook, K. S. (2001). Distinguishing the theoretical functions of social ties: Implications for support interventions. In B. R. Sarason \& S. Duck (Eds.), Personal relationships: Implications for clinical and community psychology (pp. 191-139). New York, NY: John Riley \& Sons. 
Hung, H.-T., \& Yuen, S. C.-Y. (2010). Educational use of social networking technology in higher education. Teaching in Higher Education, 15(6), 703-714.

Kabilan, M. K., Ahmad, N., \& Abidin, M. J. Z. (2010). Facebook: An online environment for learning of English in institutions of higher education? Internet and Higher Education, 13(4), 179-187. doi:10.1016/j.iheduc.2010.07.003

Keck, C. M., Iberri-Shea, G., Tracy-Ventura, N., \& Wa-Mbaleka, S. (2006). Investigating the empirical link between task-based interaction and acquisition: A meta-analysis. In J. M. Norris \& L. Ortega (Eds.), Synthesizing research on language learning and teaching (pp. 91-131). Amsterdam, Netherlands: John Benjamins.

Kinginger, C. (2011). Enhancing language learning in study abroad. Annual Review of Applied Linguistics, 31, 58-73. doi:10.1017/S0267190511000031

Kodama, Y. (2007). Japanese students' contact with native English speakers during a study abroad experience (Unpublished master's capping project). University of Alberta, Edmonton, AB, Canada.

Light, J. P. (Ed.). (2010). Building skills and expertise for using e-learning with adult ESL learners. Edmonton, AB: Alberta Employment and Immigration \& Daylight Consulting.

Long, M. (1996). The role of linguistic environment in second language acquisition. In W. Ritchie \& T. Bhatia (Eds.), Handbook of second language acquisition (pp. 413-468). San Diego, CA: Academic Press.

Macaro, E., Handley, Z., \& Walter, C. (2012). A systematic review of CALL in English as a second language: Focus on primary and secondary education. Language Teaching, 45(1), 1-42. doi:10.1017/S0261444811000395

MacIntyre, P. D., Clément, R., Dörnyei, Z., \& Noels, K. A. (1998). Conceptualizing willingness to communicate in a L2: A situational model of L2 confidence and affiliation. Modern Language Journal, 82(4), 545-562.

Mackey, A., \& Goo, J. M. (2007). Interaction research in SLA: A meta-analysis and research synthesis. In A. Mackey (Ed.), Conversational interaction in second language acquisition (pp. 407-452). New York, NY: Oxford University Press.

Madge, C., Meek, J., Wellens, J., \& Hooley, T. (2009). Facebook, social integration and informal learning at university: "It is more for socializing and talking to friends about work than for actually doing work." Learning, Media and Technology, 34(2), 141-155. doi:10.1080/17439880902923606

McCroskey, J. C. (1992). Reliability and validity of the willingness to communicate scale. Communication Quarterly, 40(1), 16-25.

McCroskey, J. C., \& Richmond, V. P. (1990). Willingness to communicate: A cognitive view. Journal of Social Behavior and Personality, 5(2), 19-37.

McDonough, K. (2007). Interactional feedback and the emergence of simple past activity verbs in L2 English. In A. Mackey (Ed.), Conversational interaction in second language acquisition (pp. 323-338). New York, NY: Oxford University Press.

Mitchell, K. (2012). A social tool: Why and how ESOL students use Facebook. CALICO Journal, 29(3), 471-493.

North, B. (2007). The CEFR illustrative descriptor scales. Modern Language Journal, 91(4), 656-659. doi:10.1111/j.1540-4781.2007.00627_3.x

Plonsky, L., \& Gass, S. (2011). Quantitative research methods, study quality, and outcomes: The case of interaction research. Language Learning, 61(2), 325-366. doi:10.1111/j.14679922.2011.00640.x

Ranta, L., \& Meckelborg, A. (2013). How much exposure to English do international graduate students really get? Measuring language use in a naturalistic setting. Canadian Modern Language Review, 69(1), 1-33. doi:10.3138/cmlr.987

Sauro, S., \& Smith, B. (2010). Investigating L2 performance in text chat. Applied Linguistics, 31(4), 554-577. doi:10.1093/applin/amq007

Schmidt, R. (1992). Psychological mechanisms underlying second language fluency. Studies in Second Language Acquisition, 14(4), 357-385. 
Schram, J. L., \& Lauver, P. J. (1988). Alienation in international students. Journal of College Student Development, 29, 146-150.

Sheen, Y. (2007). The effects of corrective feedback, language aptitude, and learner attitudes on the acquisition of English articles. In A. Mackey (Ed.), Conversational interaction in second language acquisition (pp. 301-322). New York, NY: Oxford University Press.

Smith, B. (2004). Computer-mediated negotiated interaction and lexical acquisition. Studies in Second Language Acquisition, 26(3), 365-398. doi:10.1017/S027226310426301X

Sodowsky, G. R., \& Plake, B. S. (1992). A study of acculturation differences among international people and suggestions for sensitivity to within-group differences. Journal of Counseling $\mathcal{E}$ Development, 71(1), 53-59.

Springer, S., \& Collins, L. (2008). Interacting inside and outside of the language classroom. Language Teaching Research, 12(1), 39-60.

Swain, M. (1993). The output hypothesis: Just speaking and writing aren't enough. Canadian Modern Language Review, 50(1), 158-164.

Swain, M. (1995). Three functions of output in second language learning. In G. Cook \& B. Seidlhofer (Eds.), Principle and practice in applied linguistics: Studies in honour of $H$. G. Widdowson (pp. 125-144). Oxford, UK: Oxford University Press.

Takayama, K. (2000, March). Study abroad as a contested space of local/global discourses: Japanese students' experience in the West (ERIC Document Reproduction Service No. ED451098). Paper presented at the annual conference of the Comparative and International Education Society, San Antonio, TX.

Trice, A. G. (2004). Mixing it up: International graduate students' social interactions with American students. Journal of College Student Development, 45(6), 671-687.

Valkenburg, P. M., \& Peter, J. (2009). Social consequences of the Internet for adolescents: A decade of research. Current Directions in Psychological Science, 18(1), 1-5.

Warschauer, M. (1996). Comparing face-to-face and electronic discussion in the second language classroom. CALICO Journal, 13(2), 7-25.

Williams, D. (2006). On and off the 'net: Scales for social capital in an online era. Journal of Computer-Mediated Communication, 11(2), 593-628. doi:10.1111/j.1083-6101.2006.00029.x

Yanguas, I. (2010). Oral computer-mediated interaction between L2 learners: It's about time. Language Learning \& Technology, 14(3), 72-93.

Yanguas, I. (2012). Task-based oral computer-mediated communication and L2 vocabulary acquisition. CALICO Journal, 29(3), 507-531.

Yates, L. (2004). The "secret rules of language": Tackling pragmatics in the classroom. Prospect, 19(1), 3-21.

\section{Appendix \\ Questionnaire for Data Collection}

\section{Demographics}

1. Are you male or female ?

2. How old are you? (years)

3. In what country were you born?

4. What is your first language?

5. How long have you lived in [city]? years months

6. How long do you plan to stay in [city]?

7. How long do you plan to stay in Canada/North America? years ___ months

8. Do you live alone? 
14. I have used Facebook to learn more about someone I met socially. _strongly disagree disagree neutral agree strongly agree

15. I use Facebook to learn more about other people in my classes. strongly disagree disagree neutral agree strongly agree

16. I use Facebook to learn more about my classmates from other cultures. _strongly disagree __ disagree __ neutral __ agree __ strongly agree

17. I use Facebook to learn more about other people living near me. strongly disagree __ disagree __ neutral __ agree __ strongly agree

18. I use Facebook to learn more about Canadians living near me. __strongly disagree __ disagree __ neutral __ agree __ strongly agree

19. I use Facebook to keep in touch with my friends from my same country in [city]. __strongly disagree __ disagree __ neutral __ agree __ strongly agree

20. I use Facebook to keep in touch with my friends from other countries in [city]. _strongly disagree __ disagree __ neutral __ agree __ strongly agree

21. I use Facebook to keep in touch with my Canadian friends in [city]. strongly disagree __ disagree __ neutral __ agree __ strongly agree

22. I use Facebook to keep in touch with my friends from my home country. __strongly disagree __ disagree __ neutral __ agree __ strongly agree

23. I use Facebook to meet new people. strongly disagree disagree neutral agree strongly agree

24. Using Facebook has helped me to meet new Canadians. _strongly disagree __ disagree __ neutral __ agree __ strongly agree

25. Using Facebook has helped me to become better friends with Canadians. strongly disagree __ disagree __ neutral __ agree __ strongly agree

26. Using Facebook has helped me to become better friends with people from other countries. _strongly disagree __ disagree __ neutral __ agree __ strongly agree

27. I use Facebook's chat function to talk with friends in English. strongly disagree disagree neutral agree strongly agree

28. I use Facebook to invite friends to events.

_strongly disagree ___ disagree __ neutral __ agree __ strongly agree

\section{Social Connections}

1. I feel I am part of the [city] community. __strongly disagree __ disagree __ neutral __ agree __ strongly agree

2. I am interested in what goes on in [city]. __strongly disagree __ disagree __ neutral __ agree __ strongly agree

3. [city] is a good place to be.

__strongly disagree __ disagree __ neutral __ agree __ strongly agree

4. Interacting with people in [city] makes me want to try new things. _strongly disagree __ disagree __ neutral __ agree __ strongly agree

5. Interacting with people in [city] makes me feel like a part of Canadian society. __strongly disagree __ disagree __ neutral __ agree __ strongly agree

6. I am willing to spend time to support [city] (for example, volunteering). _ strongly disagree disagree neutral agree strongly agree 
7. I meet new people in [city] all the time.

_strongly disagree disagree neutral agree strongly agree

8. I meet new Canadians in [city] all the time.

_strongly disagree disagree neutral agree strongly agree

9. There are several people in [city] I trust to solve my problems.

__strongly disagree disagree neutral agree strongly agree

10. There are several Canadians in [city] I trust to solve my problems.

_strongly disagree disagree neutral agree strongly agree

11. If I have an emergency and need to borrow $\$ 100$, I know someone in [city] who can help me.

__strongly disagree __ disagree __ neutral __ agree __ strongly agree

12. There is someone in [city] I can ask for advice about important decisions.

_strongly disagree disagree neutral agree strongly agree

13. There is a Canadian in [city] I can ask for advice about important decisions. _strongly disagree disagree neutral agree strongly agree

14. I do not know people in [city] very well so I cannot ask anyone to do important things for me.

__strongly disagree disagree neutral agree strongly agree

\section{Willingness to Communicate}

\section{Willingness to Communicate Scale (WTC)}

Directions: Below are 20 situations where a person can choose to communicate or not to communicate. Would you communicate in each type of situation? Remember, it is your choice to communicate or not. For each situation below, write the percentage of times you would choose to communicate.

$$
\begin{array}{lr}
0=\text { never } \longrightarrow & 100=\text { always } \\
\text { Example 1: Talk with a friend } & 100 \\
\text { Example 2: Talk with my brother } & 65
\end{array}
$$

1. Talk with a gas station attendant.

2. Talk with a doctor.

3. Give a presentation to a group of strangers.

4. Talk with a person you know while standing in line.

5. Talk with a salesperson in a store.

6. Talk in a large meeting of friends.

7. Talk with a police officer.

8. Talk in a small group of strangers.

9. Talk with a friend while standing in line.

10. Talk with a server in a restaurant.

11. Talk in a large meeting of people you don't know very well.

12. Talk with a stranger while standing in line.

13. Talk with a secretary.

14. Give a presentation to a group of friends.

15. Talk in a small group of people you don't know very well.

16. Talk with a garbage collector. 
17. Talk in a large meeting of strangers.

18. Talk with a husband/wife (or boyfriend/girlfriend).

19. Talk in a small group of friends.

20. Give a presentation to a group of people you don't know very well.

Language Ability Self Assessment

(adapted from Council of Europe's Self-Assessment Grid for language learning)

For each of the following skills, choose the best description of what you can do in English.

Listening

I can recognize familiar words and very basic phrases concerning myself, my family, and immediate concrete surroundings when people speak slowly and clearly.

I can understand phrases and the highest frequency vocabulary related to areas of most immediate personal relevance (e.g., very basic personal and family information, shopping, local area, employment). I can catch the main point in short, clear, simple messages and announcements.

I can understand the main points of clear standard speech on familiar matters regularly encountered in work, school, leisure, etc. I can understand the main point of many radio or TV programs on current affairs or topics of personal or professional interest when the delivery is relatively slow and clear.

I can understand extended speech and lectures and follow even complex lines of argument provided the topic is reasonably familiar. I can understand most TV news and current affairs programs. I can understand the majority of films in standard dialect.

I can understand extended speech even when it is not clearly structured and when relationships are only implied and not signalled explicitly. I can understand television programs and films without too much effort.

I have no difficulty in understanding any kind of spoken language, whether live or broadcast, even when delivered at fast native speed, provided I have some time to get familiar with the accent.

\section{Reading}

I can understand familiar names, words, and very simple sentences, for example on notices and posters or in catalogues.

I can read very short, simple texts. I can find specific, predictable information in simple everyday material such as advertisements, prospectuses, menus, and timetables, and I can understand short, simple personal letters.

I can understand texts that consist mainly of high frequency everyday or job-related language. I can understand the description of events, feelings, and wishes in personal letters.

I can read articles and reports concerned with contemporary problems in which the writers adopt particular attitudes or viewpoints. I can understand contemporary literary prose.

I can understand long and complex factual and literary texts, appreciating distinctions of style. I can understand specialized articles and longer technical instructions, even when they do not relate to my field.

I can read with ease virtually all forms of the written language, including abstract, structurally or linguistically complex texts such as manuals, specialized articles, and literary works. 


\section{Spoken Interaction}

I can interact in a simple way provided the other person is prepared to repeat or rephrase things at a slower rate of speech and help me formulate what I'm trying to say. I can ask and answer simple questions in areas of immediate need or on very familiar topics.

I can communicate in simple and routine tasks requiring a simple and direct exchange of information on familiar topics and activities. I can handle very short social exchanges, even though I can't usually understand enough to keep the conversation going myself.

I can deal with most situations likely to arise whilst travelling in an area where the language is spoken. I can enter unprepared into conversation on topics that are familiar, of personal interest, or pertinent to everyday life (e.g., family, hobbies, work, travel, and current events).

I can interact with a degree of fluency and spontaneity that makes regular interaction with native speakers quite possible. I can take an active part in discussion in familiar contexts, accounting for and sustaining my views.

I can express myself fluently and spontaneously without much obvious searching for expressions. I can use language flexibly and effectively for social and professional purposes. I can formulate ideas and opinions with precision and relate my contribution skillfully to those of other speakers.

I can take part effortlessly in any conversation or discussion and have a good familiarity with idiomatic expressions and colloquialisms. I can express myself fluently and convey finer shades of meaning precisely. If I do have a problem I can backtrack and restructure around the difficulty so smoothly that other people are hardly aware of it.

\section{Spoken Production}

I can use simple phrases and sentences to describe where I live and people I know.

I can use a series of phrases and sentences to describe in simple terms my family and other people, living conditions, my educational background, and my present or most recent job.

I can connect phrases in a simple way in order to describe experiences and events, my dreams, hopes, and ambitions. I can briefly give reasons and explanations for opinions and plans. I can narrate a story or relate the plot of a book or film and describe my reactions.

I can present clear, detailed descriptions on a wide range of subjects related to my field of interest. I can explain a viewpoint on a topical issue giving the advantages and disadvantages of various options.

I can present clear, detailed descriptions of complex subjects integrating subthemes, developing particular points, and rounding off with an appropriate conclusion.

I can present a clear, smoothly flowing description or argument in a style appropriate to the context and with an effective logical structure that helps the recipient to notice and remember significant points.

\section{Writing}

I can write a short, simple postcard, for example, sending holiday greetings. I can fill in forms with personal details, for example entering my name, nationality, and address on a hotel registration form.

I can write short, simple notes and messages relating to matters in areas of immediate needs. I can write a very simple personal letter, for example, thanking someone for something.

I can write simple connected text on topics that are familiar or of personal interest. I can write personal letters describing experiences and impressions. 
I can write clear, detailed text on a wide range of subjects related to my interests. I can write an essay or report, passing on information or giving reasons in support of or against a particular point of view. I can write letters highlighting the personal significance of events and experiences.

I can express myself in clear, well-structured text, expressing points of view at some length. I can write about complex subjects in a letter, an essay, or a report, underlining what I consider to be the salient issues. I can select style appropriate to the reader in mind.

I can write clear, smoothly flowing text in an appropriate style. I can write complex letters, reports, or articles that present a case with an effective logical structure that helps the recipient to notice and remember significant points. I can write summaries and reviews of professional or literary works. 